\title{
Testing EQ3/6 and GEMBOCHS Using Fluid-Mineral Equilibria in the Wairakei Geothermal System
}

\author{
Carol J. Bruton
}

August 28, 1995

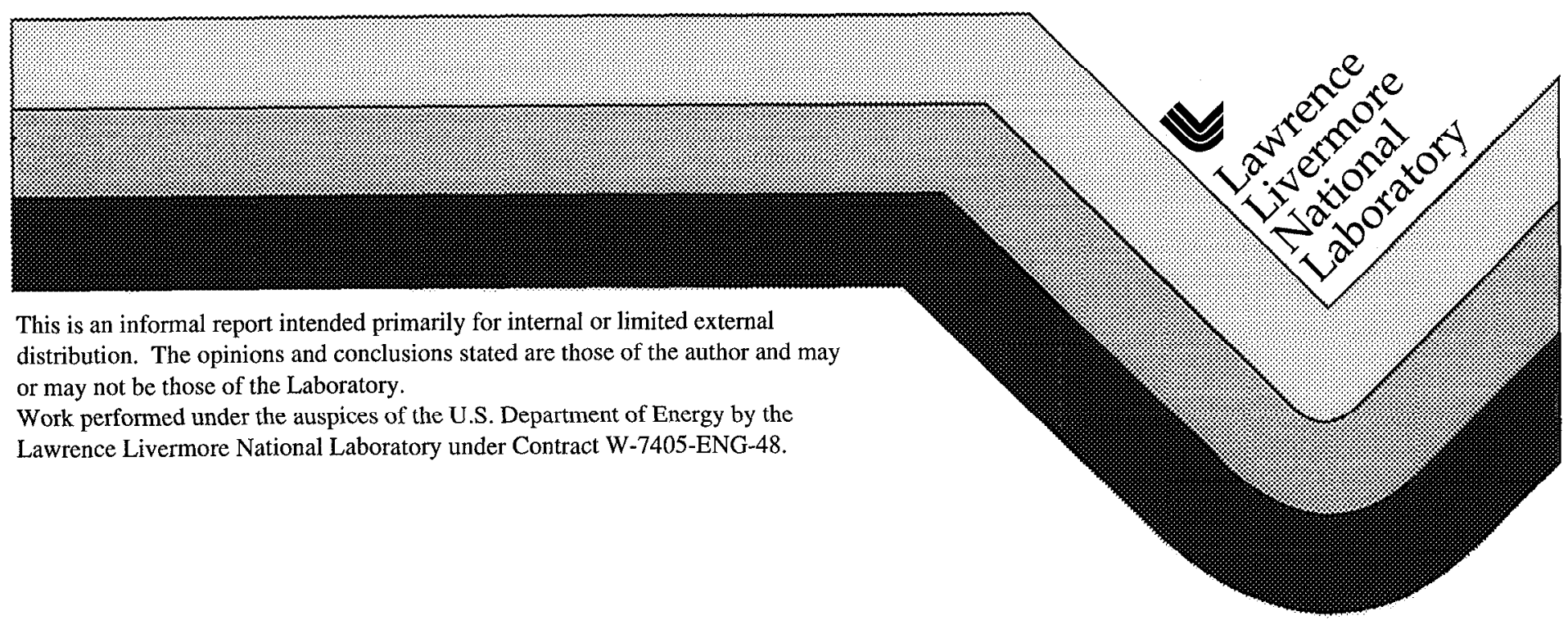




\section{DISCLAIMER}

This document was prepared as an account of work sponsored by an agency of the United States Government. Neither the United States Government nor the University of California nor any of their employees, makes any warranty, express or implied, or assumes any legal liability or responsibility for the accuracy, completeness, or usefulness of any information, apparatus, product, or process disclosed, or represents that its use would not infringe privately owned rights. Reference herein to any specific commercial product, process, or service by trade name, trademark, manufacturer, or otherwise, does not necessarily constitute or imply its endorsement, recommendation, or favoring by the United States Government or the University of California. The views and opinions of authors expressed herein do not necessarily state or reflect those of the United States Government or the University of California, and shall not be used for advertising or product endorsement purposes.

This report has been reproduced directly from the best available copy.

\section{Available to DOE and DOE contractors from the \\ Office of Scientific and Technical Information \\ P.O. Box 62, Oak Ridge, TN 37831 \\ Prices available from (423) 576-8401}

Available to the public from the National Technical Information Service

U.S. Department of Commerce 5285 Port Royal Rd.

Springfield, VA 22161 


\title{
Testing EQ3/6 and GEMBOCHS using fluid-mineral equilibria in the Wairakei geothermal system
}

\author{
Carol J. Bruton \\ Earth Sciences Division \\ Lawrence Livermore National Laboratory \\ Livermore, CA 94550
}

\begin{abstract}
Letter Report
MOL206
\end{abstract}

Chemical and Mineralogical Properties of the Waste Package Environment:

Natural System Simulations

(WBS Element 1.2.3.12.1)

August 28, 1995 


\section{Abstract}

The ability of the EQ3 and EQ6 geochemical modeling codes and the GEMBOCHS thermodynamic data bases (Wolery, 1992; Wolery and Daveler, 1992) to simulate geochemical changes in the post-emplacement environment at the potential Yucca Mountain, Nevada repository is being tested using observed mineral-fluid relations in the Taupo Volcanic Zone of New Zealand. In this report, comparisons between observed equilibria and simulations of field relations in the Wairakei geothermal system are used to test the codes and data bases in high temperature $\left(>200^{\circ} \mathrm{C}\right)$ systems.

Analysis of trends in water and gas chemistries and well discharge characteristics with time were used to identify a set of representative water and gas analyses from zones producing at about $250^{\circ} \mathrm{C}$. The most common vein minerals at this temperature are: wairakite, adularia, epidote, quartz, albite, chlorite, calcite, prehnite and pyrite (Reyes, Giggenbach and Christenson, 1993). Calculations were carried out using version 7.2a R134 of EQ3 and version 7.2a R130 of EQ6 and the SUPCRT and COM subsets of the R24 version of GEMBOCHS. Thermodynamic data bases using different data for $\mathrm{Al}$ aqueous species were used to identify the data set which produced the best matches between observed and calculated equilibria.

Geochemical calculations with EQ3/6 using measured Al concentrations and thermodynamic. data for $\mathrm{Al}$ aqueous species from Pokrovskii and Helgeson (in press) suggest that vein minerals are presently in equilibrium with subsurface fluids. Matrix replacement minerals, although of much greater variety and number than vein minerals owing to initial rock mineralogy (Reyes, Giggenbach and Christenson, 1993), are consistent with calculated mineral stabilities at downhole temperatures.

The quartz geothermometer of Fournier (1983) describes aqueous $\mathrm{SiO}_{2}$ concentrations at temperatures $>200^{\circ} \mathrm{C}$ better than calculations using quartz data from Walther and Helgeson (1977). Calculations suggest that the free energy of wairakite, a high temperature Ca-zeolite, should be decreased by about $1-1.5 \mathrm{kcal} / \mathrm{mol}$ at $250^{\circ} \mathrm{C}$. Calorimetric data for lower temperature zeolites such as clinoptilolite and stilbite from Johnson and co-workers (Johnson et al., 1991; Howell et al., 1990) appear to over-estimate the stability of these zeolites at temperatures $>200^{\circ} \mathrm{C}$.

The simulations described in this paper suggest that EQ6 can be used to identify facies of minerals that will be stable in various environments, but can not be used to predict the exact phase assemblage that is in equilibrium with a given water.

\section{Introduction}

Geochemical modeling codes such as EQ3/6 (Wolery, 1992; Wolery and Daveler, 1992) will be used for making bounding calculations of the geochemical response of the potential Yucca Mountain repository to the emplacement of high-level nuclear waste. Storage of nuclear waste in a geologic repository may subject the components of the repository, such as the engineered barrier system and the altered zone, to temperature fluctuations, changes in fluid flow, chemical changes, ionizing radiation and other phenomena. Numerical models of the post-emplacement environment at the potential Yucca Mountain site by Buscheck and Nitao (1993) show the potential for peak temperatures about $200^{\circ} \mathrm{C}$ near the waste, and attendant changes in relative humidity, 
"drying-out", boiling, condensation, one- and two-phase fluid flow, mineral precipitation and dissolution, ion exchange and surface complexation.

Bruton, Glassley and Meike (1995) discuss the potential for using geothermal areas such as those in the Taupo Volcanic Zone (TVZ) in New Zealand as natural analogues to many of the processes that are anticipated to occur in the post-emplacement environment at Yucca Mountain. This letter report documents recent research being carried out using data from the TVZ to test the ability of the EQ3/6 geochemical modeling codes and their associated GEMBOCHS thermodynamic data bases to model mineral-fluid relations in natural systems. In particular, the natural systems were used: 1) to test under what conditions and in what manner EQ3/6 can be used to forecast changes in rock and fluid chemistry during the flow of heated fluids through silicic rocks; and 2) to test the thermodynamic data in GEMBOCHS and to select appropriate thermodynamic data when multiple sources exist, for use in predicting mineralogical and fluid chemistry changes in the near-field and altered zone of the potential Yucca Mountain repository.

The work described here will focus on mineral equilibria and fluid chemistry in the Wairakei geothermal field at temperatures of about $250^{\circ} \mathrm{C}$. Additional studies are evaluating fluid chemistry and accompanying secondary mineralogy in the temperature range of $100-200^{\circ} \mathrm{C}$. To accomplish this work, it is necessary to select representative water and gas compositions from Wairakei wells (called boreholes), reconstruct downhole fluid compositions, calculate the minerals predicted to be in equilibrium with each fluid, and compare simulation results with observed vein and vug mineralogy. The comparisons between simulation results and observed mineralogy reveal:

1) The quartz solubility data at elevated temperatures $\left(250^{\circ} \mathrm{C}\right)$ that best describes aqueous silica concentrations.

2) The choice of thermodynamic data for aqueous aluminum (Al) species that best describes observed equilibria at about $250^{\circ} \mathrm{C}$.

2) The importance of determining the fugacity of $\mathrm{CO}_{2}$ in the gas phase with regard to its ability to influence solution $\mathrm{pH}$ and fluid reactivity.

3) Recommended corrections to the thermodynamic data for wairakite, a zeolite which forms at temperatures above about $200^{\circ} \mathrm{C}$.

4) Problems with thermodynamic data for zeolites and computed zeolite stabilities.

5) Ability to predict stable mineral assemblages using EQ3/6

6) Vein/vug vs. matrix mineralogy and mineral assemblages

All calculations described in this paper were carried out using version 7.2a R134 of EQ3 and version 7.2a R130 of EQ6. The SUPCRT and COM subsets of the R24 version of GEMBOCHS were used as indicated.

Fluid chemistry: Choice of representative waters and gases

Reyes, Giggenbach and Christenson (1993) reviewed available well discharge data for the 
Wairakei area. Most of the more detailed and precise work on well discharges was from wells in the Waiora area near the productive Waiora Fault. These wells were therefore focused on in this study.

Water samples were collected from the weirbox of the silencers at atmospheric pressure after steam separation. Collection at this point minimizes variations in fluid composition caused by incorporation of excess steam during production. Weirbox data show some variation with time in almost all wells owing probably to dilution and cooling in the hydrothermal reservoir. These changes are relatively minor, however, and the earliest analyses from each well may best represent undisturbed downhole conditions, especially if the data coincide with dilution trends, and if the discharge enthalpy shows no excess enthalpy.

To reconstruct downhole fluid chemistries, the separated vapor phase must be added back to the water in proportion to the separated steam fraction. During production, reduction of pressure causes the downhole fluid to boil and separate into a water and vapor phase. The separated vapor is dominated by $\mathrm{H}_{2} \mathrm{O}$, but also contains smaller quantities of the gases $\mathrm{CO}_{2}, \mathrm{H}_{2} \mathrm{~S}$ and $\mathrm{H}_{2}$.

Water and gas samples were chosen from Wairakei geothermal field boreholes WK-28, 72 and 81 as being most representative of original, undisturbed downhole fluids. Selection was based on discharge characteristics and chemical trends with time. Criteria included (not necessarily in order of priority):

1) lack of excess enthalpy

2) gas analysis was done at about the same time water was analyzed

3) cation and anion concentrations were similar to other samples, after accounting for steam loss

4) low $\mathrm{CO}_{2} / \mathrm{H}_{2} \mathrm{~S}$ molar ratio in the vapor phase (this ratio tends to be high in initial samples, which when paired with high excess enthalpy suggests that a two-phase zone has developed downhole in an area that used to be single phase)

5) correspondence of temperatures predicted by chemical geothermometers (e.g. quartz adiabatic, enthalpy, Na-Ca-K; see Henley, Truesdell and Barton, 1984)

On the basis of these criteria, the following samples from Reyes, Giggenbach and Christenson (1993) were considered:

WK-28 water and gas samples dated 3-60

WK-72 water sample 4-61 and gas samples 5-61 and 3-78

WK-81 water sample 10-74 and gas sample 11-74

To correct for steam loss during production, the quartz adiabatic geothermometer is used. The adiabatic quartz geothermometer assumes that the downhole fluid is saturated with respect to quartz, and that the fluid undergoes adiabatic, single-stage steam loss from the downhole temperature to $100^{\circ} \mathrm{C}$ upon production. This assumes that maximal steam loss occurs at $100^{\circ} \mathrm{C}$ at $1 \mathrm{bar}$, and at Wairakei the separation pressure equals 1 bar. Table 1 lists the "as-sampled" water analyses from Reyes, Giggenbach and Christenson (1993), and the water analyses after correction for boiling, along with dates of sampling, geothermometer temperatures and so on as annotated in the table. Table 2 lists the gas components of the vapors that were added back to each water along 
Table 1. Major constituents of discharge from Wairakei wells WK-28 (sampled on 3/60), WK-72 (sampled on 4/61) and WK81 (sampled on 10/74) (in mg/kg) (from Reyes, Giggenbach and Christenson, 1993).

\begin{tabular}{|c|c|c|c|c|c|c|}
\hline Component & $\begin{array}{l}\text { WK-28 } \\
\text { analyzed }\end{array}$ & $\begin{array}{l}\text { WK-28 } \\
\text { corrected }^{*}\end{array}$ & $\begin{array}{l}\text { WK-72 } \\
\text { analyzed }\end{array}$ & $\begin{array}{l}\text { WK-72 } \\
\text { corrected }^{*}\end{array}$ & $\begin{array}{l}\text { WK-81 } \\
\text { analyzed }\end{array}$ & $\begin{array}{l}\text { WK-81 } \\
\text { corrected* }\end{array}$ \\
\hline $\mathrm{Na}$ & 1260 & 898 & 1295 & 942 & 1256 & 917 \\
\hline $\mathrm{K}$ & 200 & 142 & 215 & 157 & 182 & 133 \\
\hline$\overline{\mathrm{Ca}}$ & 16 & 11.4 & 18 & 13 & 22 & 16 \\
\hline $\mathrm{Mg}$ & 0.035 & 0.025 & 0.014 & 0.01 & 0.0035 & 0.0026 \\
\hline $\mathrm{Fe} *$ & $\mathrm{NA}$ & $0.6 e-6$ & NA & $0.38 \mathrm{e}-3$ & NA & $0.19 \mathrm{e}-2$ \\
\hline $\mathrm{Al} * *$ & $\mathrm{NA}$ & 0.27 & NA & 0.26 & 0.37 & 0.27 \\
\hline $\mathrm{Rb}$ & $\mathrm{NA}$ & NA & NA & NA & 2.52 & 1.8 \\
\hline $\mathrm{Li}$ & 14 & 10 & 12.9 & 9.4 & 11.8 & 8.6 \\
\hline Cs & NA & NA & NA & $\mathrm{NA}$ & 2.4 & 1.8 \\
\hline B & 28.2 & 20 & NA & NA & 25.3 & 19 \\
\hline $\mathrm{Cl}$ & 2213 & 1530 & 2241 & 1636 & 2083 & 1587 \\
\hline $\mathrm{HCO}_{3}$ & 48 & 979 & NA & 345 & NA & 41 \\
\hline $\mathrm{SO}_{4}$ & 34 & 24 & $34 * * *$ & 20 & 34 & 25 \\
\hline $\mathrm{H}_{2} \mathrm{~S}^{* * * *}$ & NA & 15 & NA & 9 & NA & 4 \\
\hline $\mathrm{SiO}_{2}$ & 660 & 470 & 600 & 438 & 612 & 447 \\
\hline $\mathrm{pH}$ & $8.2\left(20^{\circ} \mathrm{C}\right)$ & $6.3\left(246^{\circ} \mathrm{C}\right)$ & $8.3\left(20^{\circ} \mathrm{C}\right)$ & $6.2\left(239^{\circ} \mathrm{C}\right)$ & $7.4\left(20^{\circ} \mathrm{C}\right)$ & $6.1\left(240^{\circ} \mathrm{C}\right)$ \\
\hline $\mathrm{TQA}^{* * * * *}$ & & $246^{\circ} \mathrm{C}$ & & $239^{\circ} \mathrm{C}$ & & $240^{\circ} \mathrm{C}$ \\
\hline \multicolumn{7}{|c|}{$\begin{array}{l}\text { * corrected for steam and gas loss; calculated assuming equilibrium with pyrite at TQA; Cl } \\
\text { adjusted to obtain electrical neutrality } \\
* * \text { from analysis of other samples from same wells } \\
* * * \text { from average of other samples from WK-72 } \\
* * * * \text { analyzed value for all samples assumed to equal } 0.3 \mathrm{mg} / \mathrm{kg} \text {, typical of WK-28 waters. } \\
* * * * * \text { downhole temperature calculated from the adiabatic quartz geothermometer (TQA) using } \\
\text { quartz solubility data from Fournier }(1983)^{\mathrm{b}}\end{array}$} \\
\hline
\end{tabular}

a. The previous study by Bruton, Glassley and Bourcier (1994) assumed that Al concentration was controlled by equilibrium with K-feldspar.

b. Implications of using data from Fournier (1983) vs. Walther and Helgeson (1977) for quartz solubility will be discussed later in the report.

Table 2. Major chemical components of vapors discharged from Wairakei wells WK-28, 72 and 81 sampled on $3 / 60,5 / 61$ and $11 / 74$, respectively (in $\mu \mathrm{mol} / \mathrm{mol}$ water)

\begin{tabular}{|l||l|l|l|}
\hline Component & WK-28 & WK-72 & WK-81 \\
\hline $\mathrm{CO}_{2}$ & 279 & 102 & 12 \\
\hline $\mathrm{H}_{2} \mathrm{~S}$ & 8 & 4.5 & 1.9 \\
\hline
\end{tabular}

with steam $\left(\mathrm{H}_{2} \mathrm{O}\right)$.

The choice of the representative gas composition for each well is not straightforward. Even though the separated water composition may show little variation, gas phase chemistry varies significantly over time for the wells, as illustrated in Figure 1. Changes of this magnitude will greatly 


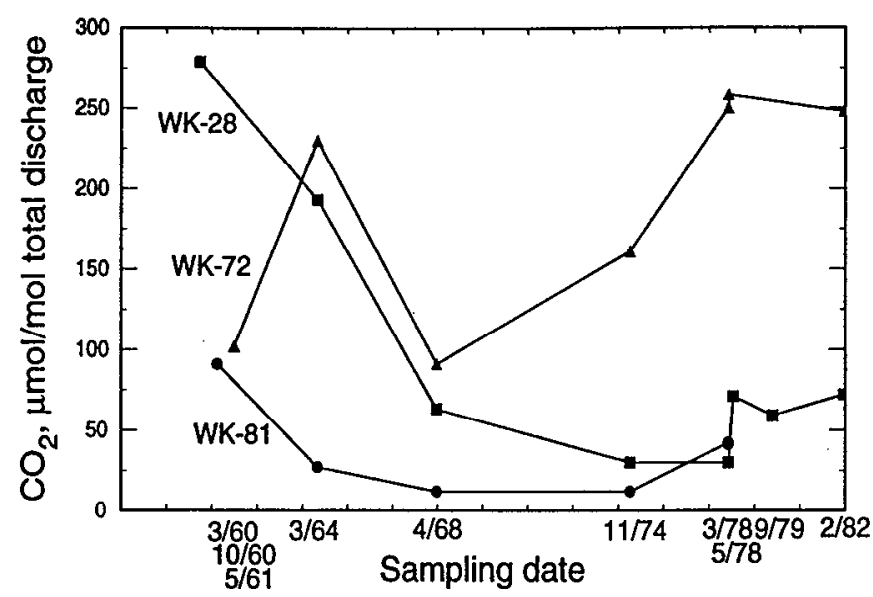

Figure $1 . \mathrm{CO}_{2}$ concentrations (in $\mu \mathrm{mol} / \mathrm{mol}$ water) measured in Wairakei wells WK-28, 72 and 81 as a function of timc.

impact calculated fluid-mineral equilibria owing to its impact on $\mathrm{pH}$. A later section addresses the consequences on predicted equilibria of variations in gas chemistry.

Redox state was set by the $\mathrm{SO}_{4}=/ \mathrm{H}_{2} \mathrm{~S}$ buffer, assuming an initial concentration of aqueous $\mathrm{H}_{2} \mathrm{~S}$ of $0.3 \mathrm{mg} / \mathrm{kg}$ in WK-28 based on concentration data from nearby wells. This assumption represents an initial test of modeling strategies regarding control of redox in the subsurface. Future models may use the fugacity of $\mathrm{H}_{2}(\mathrm{~g})$ to control the ratio of sulfide to sulfate (Christenson, 1987).

This initial study did not focus on phases containing $\mathrm{Mg}, \mathrm{Fe}$, and/or $\mathrm{S}$ as primary components. The latter two elements are strongly dependent on redox state, which can vary significantly in hydrothermal systems owing to boiling. Chlorite is the major mineral phase containing $\mathrm{Mg}$ in these systems, but no chlorite solid solutions are provided for in the SUPCRT data base. The COM data file provides for an ideal solid solution model for chlorite as well as saponites, which are Mg-rich smectites. Clay stabilities may be addressed in future studies.

\section{Alteration mineralogy}

Alteration mineralogy in the Wairakei wells of interest are described in Reyes, Giggenbach and Christenson (1993) and references included therein, and summarized in Bruton, Glassley and Bourcier (1994). Portions of the following are taken directly from Bruton, Glassley and Bourcier (1994).

Alteration mineralogy at Wairakei varies strongly with temperature. Hydrothermal minerals identified at various depths (excluding the acid condensate zones) include epidote, calcite, pyrite, smectite, chlorite and silica polymorphs, plus the zeolites wairakite, mordenite, clinoptilolite and laumontite. Alteration mineralogy seems to be strongly controlled by temperature. A representative set of minerals, called a mineral facies, is composed of secondary minerals which commonly occur in a given temperature range. The minerals in the facies occur in various combinations, called mineral assemblages. Different mineral assemblages in a given facies can coexist on spatial scales as small as a single hand specimen or petrographic thin section. 
Mineral assemblages identified at downhole temperatures of $240-260^{\circ} \mathrm{C}$ in the main feed zones at Wairakei include (Reyes, Giggenbach and Christenson, 1993; Steiner, 1977):

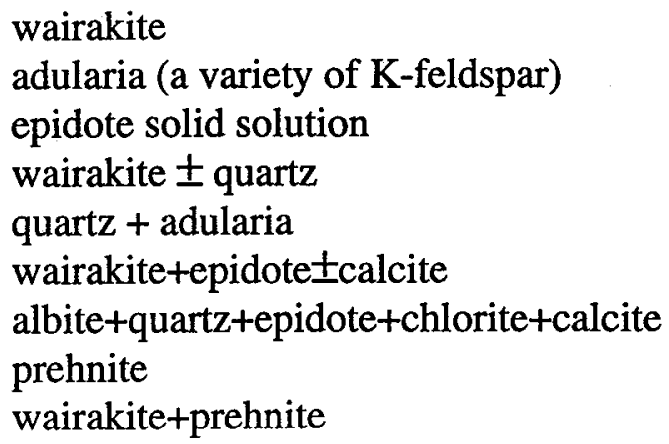

The above mineral assemblages contain the secondary minerals in wells WK-28, 72 and 81 that coexist with the fluids described in the previous section. The ability of EQ3/6 and its data bases to forecast the stability of these assemblages and the minerals they contain is the focus of this letter report.

\section{Calculational approach}

This work expands on that of Bruton, Glassley and Bourcier (1994), who discussed computed vs. observed equilibria in one well each from the Wairakei (WK-28) and Kawerau (KA-21) geothermal fields. In this study, three reconstructed downhole fluids were used to compute predicted secondary mineralogy at depth, which was then compared to observed mineral equilibria at the downhole temperature.

The approach taken was as follows.

- Select representative sets of coexisting water and gas analyses from Wairakei wells and reconstruct downhole fluid chemistry by adding steam and gases lost during production back into the liquid phase (see previous section Fluid chemistry).

- Identify mineral assemblages along fractures and flow zones closely associated with source of produced fluids (see previous section Alteration mineralogy).

- Calculate affinity $(A)$ of potential secondary minerals where $A=R T \ln (Q / K)^{1}$ using versions 7.2a R134 of EQ3, version 7.2a R130 of EQ6 and version R24 of the SUPCRT and COM subsets of the GEMBOCHS thermodynamic data base.

- Compare calculated and observed mineral equilibria.

Phase relations were examined with the use of affinity-temperature diagrams. Affinity is a measure of a mineral's saturation state. If:

$A=0$, the mineral is at equilibrium with the solution

$\mathrm{A}<0$, the mineral is undersaturated with respect to the solution

1. $\mathrm{Q}=$ ion activity product; $\mathrm{K}=$ equilibrium constant; $\mathrm{R}=$ gas constant; $\mathrm{T}=$ temperature in $\mathrm{K}$. 
$A>0$, the mineral is supersaturated with respect to the solution

As mentioned in Bruton, Glassley and Bourcier (1994), potential mineral assemblages are inferred when multiple affinity-temperature curves have a common intersection at $A=0$. Identification of potential mineral assemblages in this manner is especially useful when thermodynamic data may be suspect or kinetics controls the formation of precipitates. Downhole temperature can be estimated by noting the temperature at which the affinity curves converge on zero (equilibrium).

Calculations in this paper assume that pressures correspond to the liquid/vapor saturation curve for $\mathrm{H}_{2} \mathrm{O}$. Possible implications of this assumption for the silica geothermometer are discussed elsewhere in this paper; the consequences are assumed to be minimal for most reactions.

Solid solutions for epidote and muscovite were considered in the calculations. Clinozoisite as used in this paper refers to the clinozoisite end member of an ideal epidote solid solution (Bird and Helgeson, 1980) with an activity of 0.4 , as calculated from microprobe analyses of epidote at Wairakei. Muscovite refers to the muscovite end member of an ideal illite solid solution with an activity of 0.5 . Microprobe analyses of Wairakei illites were not available. However, Christenson (1987) determined that the muscovite end member had an average activity of 0.54 in the Kawerau geothermal field in New Zealand. This value was used as a first approximation. As can be seen in the following figures, the stability of the clinozoisite end member is described quite well, whereas the predicted stability of the muscovite end member varies widely, for reasons to be discussed later.

\section{Results: Water-rock equilibrium calculations}

Comparisons between predicted and observed mineral stabilities that will be described in the following sections allowed us to determine:

1) Quartz solubility data that best describes controls of aqueous silica concentrations at tempcratures greater than about $200^{\circ} \mathrm{C}$.

2) Importance of gas phase chemistry on mineral equilibria, and mineral indicators of variations in $\mathrm{pH}$.

3) Thermodynamic data for aqueous $\mathrm{Al}$ species that best describe mineral stabilities at temperatures greater than about $200^{\circ} \mathrm{C}$.

4) Corrections to thermodynamic data for wairakite, a high temperature zeolite.

5) Need for better usage and interpretation of calorimetric thermodynamic data for zeolites.

6) Appropriateness of utilizing the mineral facies concept to infer mineral stability rather than exact prediction of the precise secondary minerals to precipitate at temperature.

7) Number and identity of coexisting minerals in veins and vug fills vs. matrix (i.e. potential application of the phase rule).

Points 1 through 6 will be demonstrated using affinity-temperature diagrams for Wairakei wells WK-28, 72 and 81 generated with the SUPCRT92-based version sup.R24 of GEMBOCHS. 
Factors related to choice of data bases and zeolite thermodynamic data referred to in point 5 are demonstrated by comparing results using the SUPCRT and COM versions of GEMBOCHS. Point 7 was revealed by the petrologic observations of Reyes described in Reyes, Giggenbach and Christenson (1993).

In all affinity-temperature diagrams, some discretion was used to select the minerals to be plotted. Phases were chosen based on their occurrence in observed mineral assemblages, and their extent of supersaturation or closeness to equilibrium. Minerals that were generally depicted on the diagrams include: quartz, K-feldspar, albite, muscovite, calcite, prehnite, wairakite and clinozoisite. These minerals most often appear in stable mineral assemblages identified by Reyes in the temperature range $240-260^{\circ} \mathrm{C}$ (Reyes, Giggenbach and Christenson, 1993) (see earlier section Alteration mineralogy). Minerals containing $\mathrm{Mg}$, Fe and $\mathrm{S}$ were not focused on, as discussed earlier.

\section{Choice of quartz solubility data: Well WK-81}

Figure 2 shows differences in the concentrations of $\mathrm{SiO}_{2}(\mathrm{aq})$ predicted according to quartz

Quartz solubility

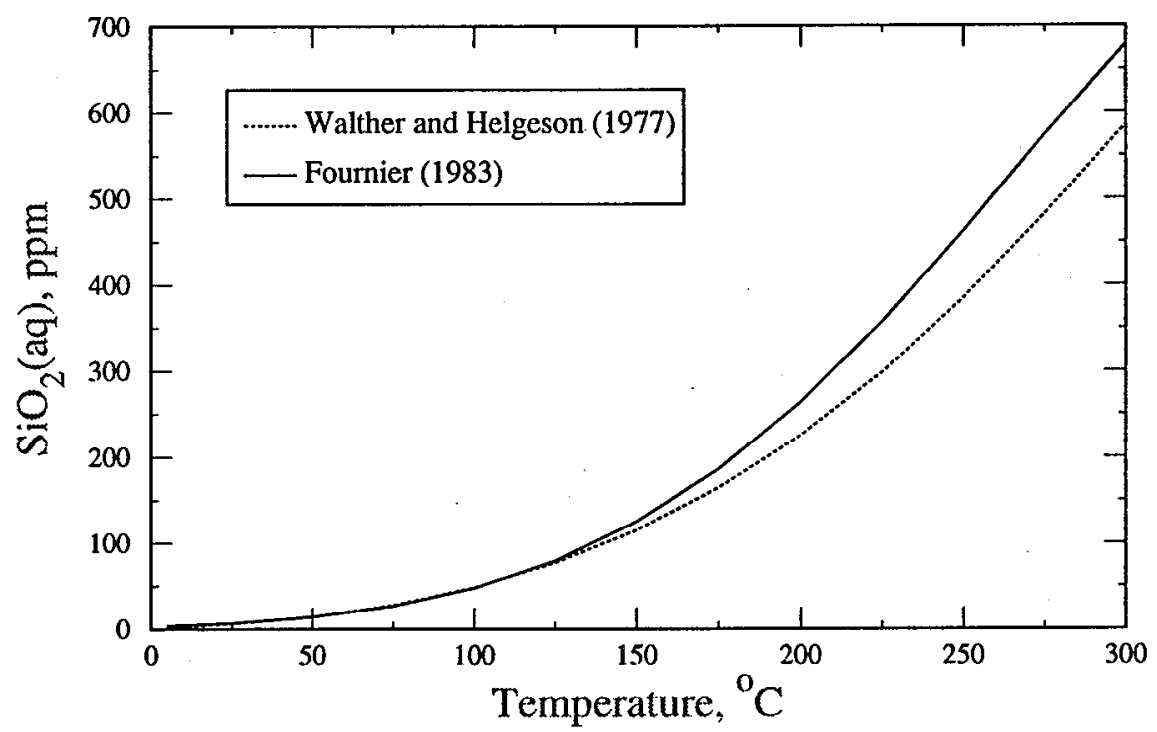

Figure 2. $\mathrm{SiO}_{2}(\mathrm{aq})$ concentrations in equilibrium with quartz using thermodynamic data from Walther and Helgeson (1977) and Fournier (1983).

solubility data from Walther and Helgeson (1977) and Fournier (1983). Fournier's data predict significantly higher $\mathrm{SiO}_{2}(\mathrm{aq})$ concentrations in solution than the quartz solubility data of Walther and Helgeson (1977) at temperatures exceeding about $150^{\circ} \mathrm{C}$. Calculated mineral equilibria more closely correspond to observed mineralogy when Fournier's (1983) quartz geothermometer is used. For example, Figures 3 and 4 contrast computations of mineral equilibria in Wairakei well WK-81 using the Fournier (1983) and Walther and Helgeson (1977) data base, respectively.

The adiabatic quartz geothermometer based on data from Walther and Helgeson predicted a 


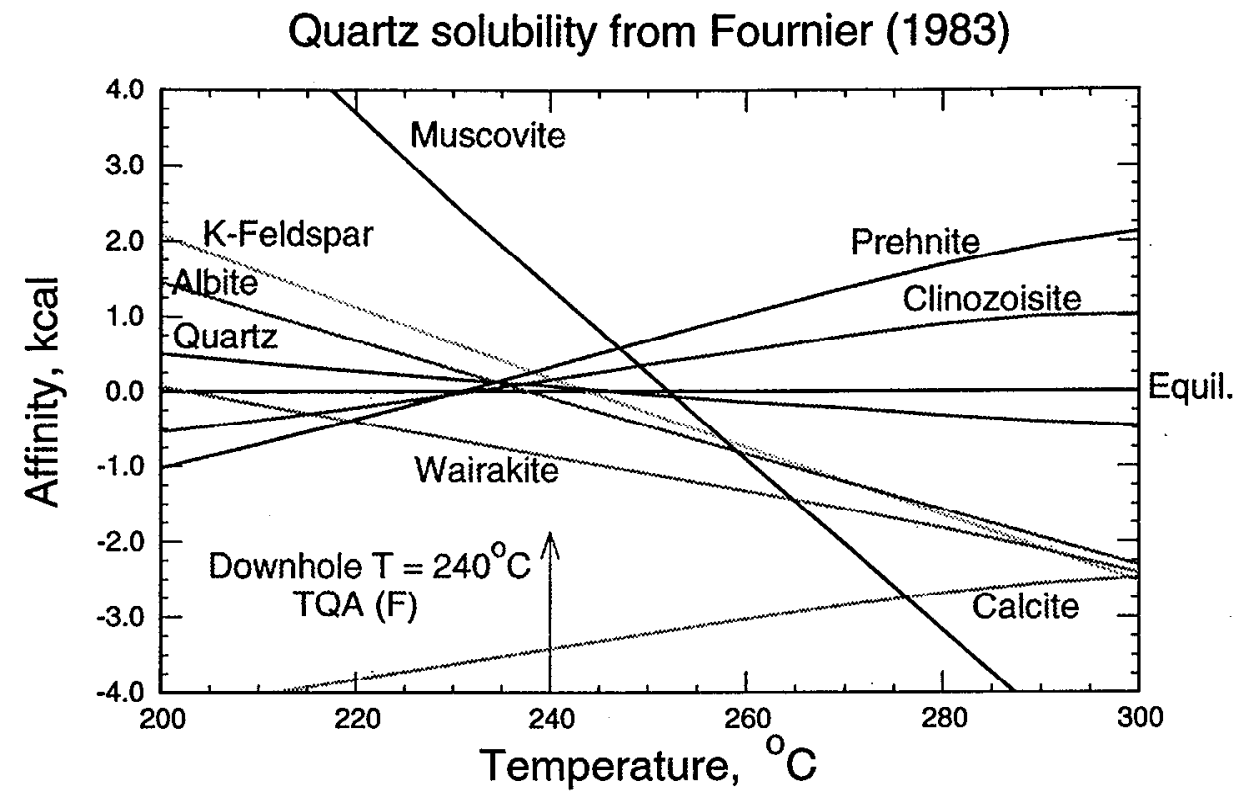

Figure 3. Affinity vs. temperature diagram for well WK-81 using quartz solubility from Fournier (1983).

Quartz solubility from Walther and Helgeson (1977)

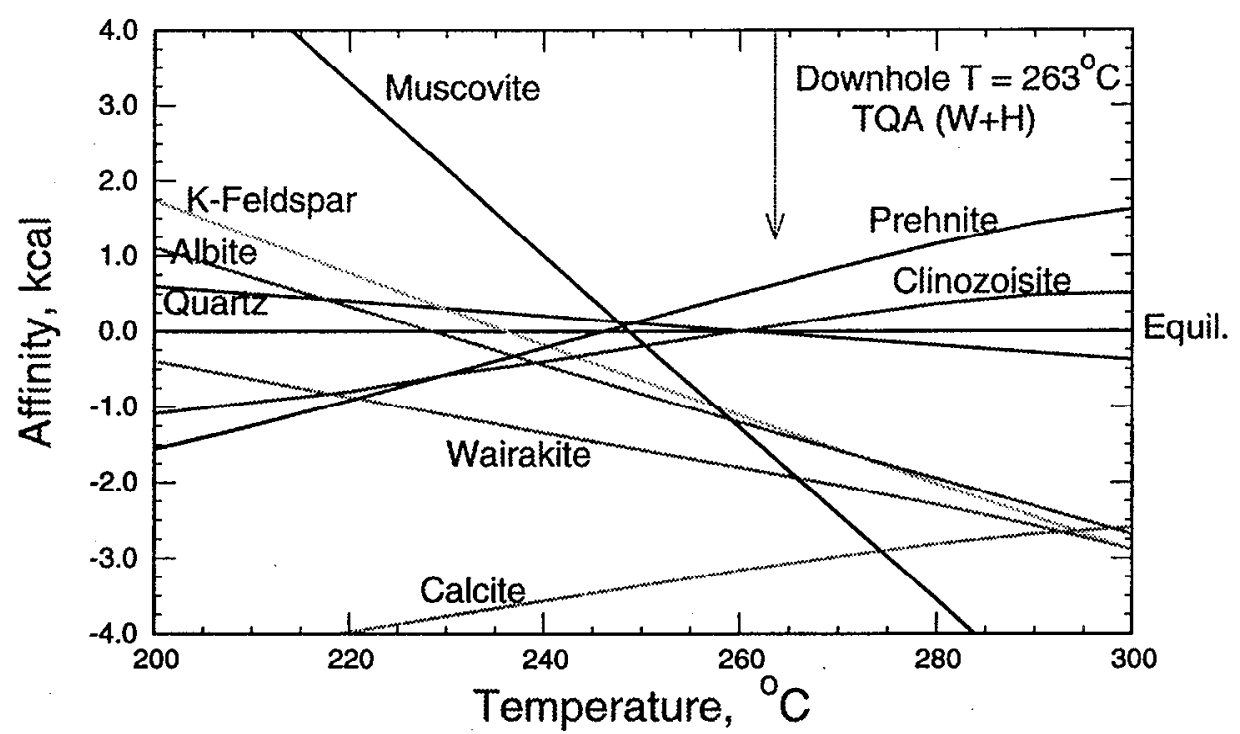

Figure 4. Affinity vs. temperature diagram for well WK-81 using quartz solubility from Walther and Helgeson (1977).

downhole temperature of $263^{\circ} \mathrm{C}$, whereas that of Fournier predicted $240^{\circ} \mathrm{C}$. As can be seen from Figures 3 and 4, the affinity curves seem to converge more closely on the downhole temperature predicted using the Fournier (1983) quartz solubility data.

For calculations of quartz solubility above about $200^{\circ} \mathrm{C}$ at the present time, I therefore recommend that the quartz solubility data of Fournier (1983) be used in place of that of Walther and 
Helgeson (1977) that is contained in all current versions of GEMBOCHS. However, the effect of pressure on quartz solubility must be considered in future simulations. Ragnarsdottir and Walther (1983) conclude that pressure significantly affects quartz solubilities at $250^{\circ} \mathrm{C}$, and can account for the discrepancy between results of Fournier and those of Walther and Helgeson. Calculations with GEMBOCHS are currently restricted to the liquid/vapor saturation curve for $\mathrm{H}_{2} \mathrm{O}$.

\section{Impact of changes in gas chemistry: WK-72}

Vapor compositions vary with time owing to production and the partitioning of components between vapor and liquid phases. Figure 1 shows the variation of $\mathrm{CO}_{2}$ with time in wells WK-28, 72 and 81 . Changes of this magnitude will greatly impact calculated fluid-mineral equilibria owing to its impact on $\mathrm{pH}$. The variation of component ratios, discharge enthalpy and other well parameters with time can be used to try to derive reasonable estimates of the quantity of volatile species in the original, undisturbed fluids. However, uncertainties persist.

Use of different gas compositions for a given fluid analysis can produce significant changes in predicted mineralogy owing to the impact of $\mathrm{CO}_{2}$ on $\mathrm{pH}$. The greater the $\mathrm{CO}_{2}$ content of the produced vapors, the lower the predicted $\mathrm{pH}$ of the reconstructed downhole fluid. For example, the calculated downhole $\mathrm{pH}$ is reduced from 6.2 to 5.9 when the $3 / 78$ gas analysis for WK-72 with $258 \mathrm{mmol} \mathrm{CO} 2 / \mathrm{mol} \mathrm{TD}$ is used rather than the $5 / 61$ analysis with $102 \mathrm{mmol} \mathrm{CO} / \mathrm{mol} \mathrm{TD}$, where TD is defined as the total discharge, that is, the combined chemistry of the steam and liquid phases.

Figures 5 and 6 illustrate the mineralogical consequences of using the high (3/78) and low (5/ 61) $\mathrm{CO}_{2}$ gas estimates, respectively. The stabilities of $\mathrm{K}$-feldspar and albite are largely unaffected by changes in $\mathrm{pH}$, whereas the stabilities of prehnite, muscovite and calcite are sensitive to $\mathrm{pH}$, as reflected by the shift of their affinity-temperature curves. The dissolution/precipitation of muscovite, prehnite and calcite may thus serve as sensitive indicators of changes in downhole fluid chemistry. In contrast, the stabilities of $\mathrm{K}$-feldspar and albite are largely unaffected by uncertainties in gas chemistry and $\mathrm{pH}$, and are therefore good tests of equilibrium and the adequacy of thermodynamic data for aqueous $\mathrm{Al}$ species.

Figures 5 and 6 also suggest that the earlier, lower $\mathrm{CO}_{2}$ gas analysis better represents downhole conditions, as shown by the fact that the curves tend to converge more closely on the downhole temperature than in the high $\mathrm{CO}_{2}$ gas case.

This finding may have implications for Yucca Mountain with regard to the timing and mass of ${ }^{14} \mathrm{C}$ release. If released as $\mathrm{CO}_{2}$ and in sufficient quantities while water is present, the waters can be made more chemically aggressive if initially neutral, or neutralized if initially alkaline from contact with cementitious materials in the engineered barrier system. The consequences of interactions with cementitious materials before contact with tuff must also be taken into account.

Of perhaps more importance is the variation in gas phase chemistry, particularly $\mathrm{CO}_{2}$ content, in the vapor phase in the two-phase (gas and water) zones predicted to occur by Buscheck and Nitao (1993). The $\mathrm{CO}_{2}$ content will control the $\mathrm{pH}$ of the fluid with which it is in contact, and thus the extent and type of fluid-rock interaction. The fluid-rock interaction, in turn, may have a large impact on tuff permeability and fluid flow pathways. Bruton and Viani (1992) suggested that water may behave as if it were $100 \%$ saturated at liquid saturations greater than about $20 \%$ at 
High $\mathrm{CO}_{2}$ gas ( $3 / 78$ analysis)

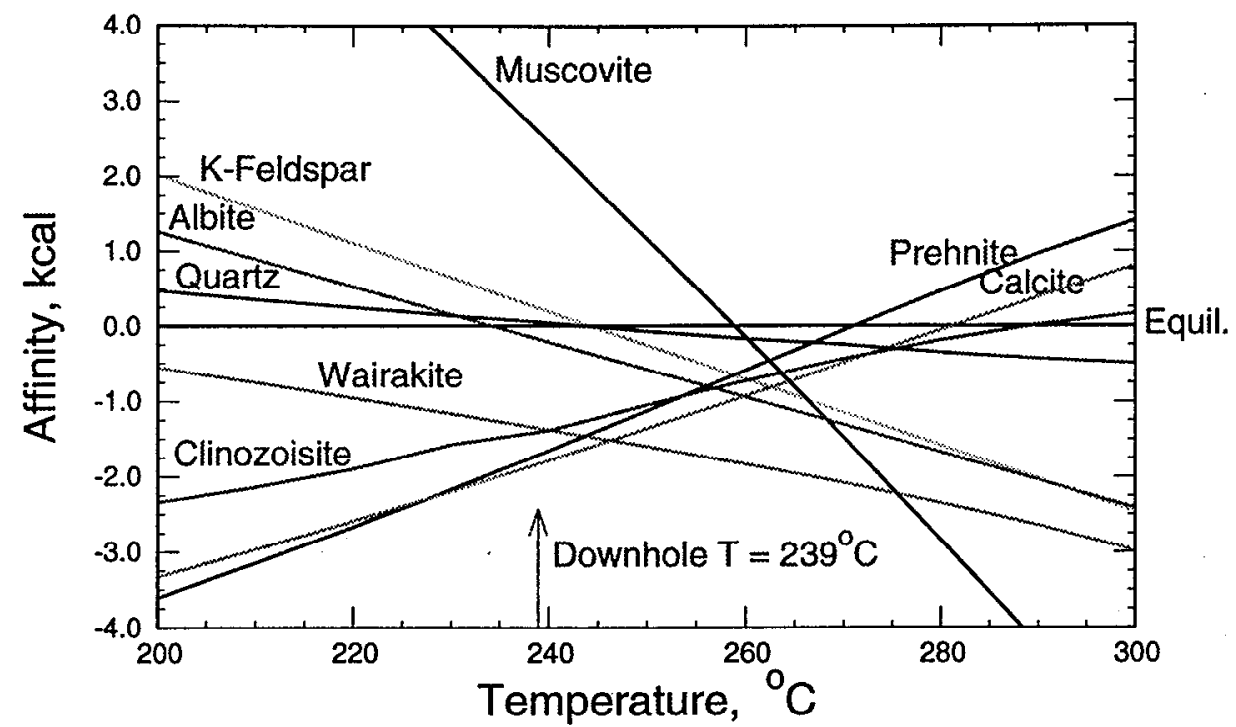

Figure 5. Affinity vs. temperature diagram for well WK-72 using $3 / 78$ gas analysis with $258 \mathrm{mmol} \mathrm{CO}_{2} / \mathrm{mol} \mathrm{TD}$ (see text). Quartz data from Fournier (1983).

Low $\mathrm{CO}_{2}$ gas (5/61 analysis)

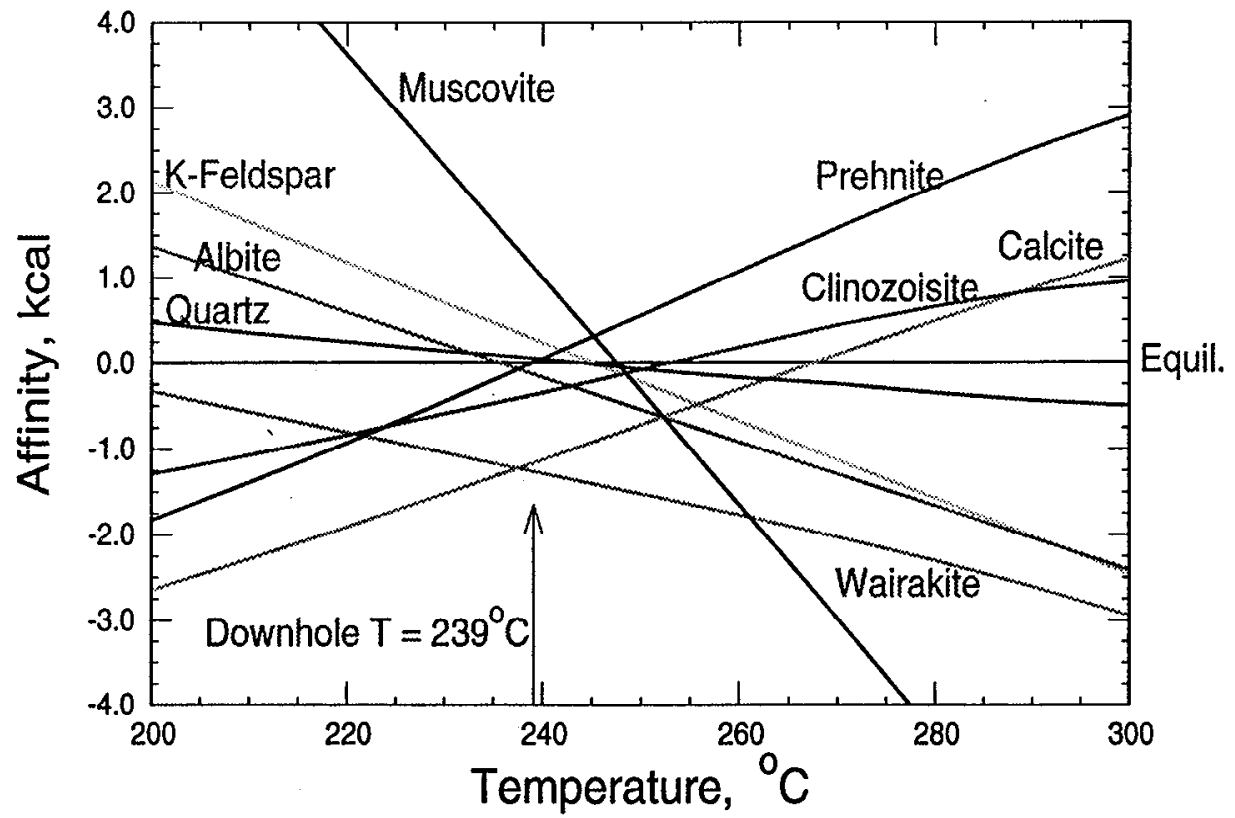

Figure 6. Affinity vs. temperature diagram for well WK-72 using $5 / 61$ gas analysis with $102 \mathrm{mmol} \mathrm{CO}_{2} / \mathrm{mol} \mathrm{TD}$ (see text). Quartz data from Fournier (1983).

temperatures up to $100^{\circ} \mathrm{C}$. However, the coexisting gas phase will have a large impact on the 
water's chemical reactivity. Any forecasts of fluid-rock interaction in two-phase zones will require the gas phase chemistry to be considered, as addressed in the boiling scenarios evaluated by Criscenti and Arthur (1991) and Arthur and Murphy (1989).

\section{Thermodynamic data for aqueous $\mathrm{Al}$ species: WK-28}

Downhole mineral equilibria in well WK-28 were calculated using two different data bases that are in current use. One is based on SUPCRT92, and the other is an updated version of the same data base but with thermodynamic data for aqueous Al species from Pokrovskii and Helgeson (in press) (SUPCRT R24). The latter data is being considered for inclusion into GEMBOCHS (and will be, at the time this letter report is submitted).

Figure 7 shows the simulation results using data from Pokrovskii and Helgeson, whereas Figure 8 was constructed using the SUPCRT92 data base. The convergence of affinity curves at zero affinity (equilibrium) at the downhole temperature in Figure 7 for phases that are observed as secondary phases suggests that Pokrovskii and Helgeson's data for aqueous Al species works quite well. In contrast, the data in SUPCRT92 ${ }^{2}$ do not reproduce downhole mineralogy well. In these calculations, measured $\mathrm{Al}$ concentrations were used; that is, they were not automatically set using mineral equilibria as is often done, especially at lower temperature (e.g Bowers and Burns, 1990; Chipera, Bish and Carlos, 1995).

Given the above results, I recommend that thermodynamic data for aqueous $\mathrm{Al}$ species be sourced from Pokrovskii and Helgeson (in press). Further simulations to be undertaken in the range $100-200^{\circ} \mathrm{C}$ will attempt to evaluate the $\mathrm{Al}$ data bases at lower temperature. However, less discrepancy may be observed at lower temperatures because the main cause of discrepancy is the $\log \mathrm{K}$ for reaction between $\mathrm{Al}^{3+}$ and $\mathrm{AlO}_{2}^{-}$; the two log $\mathrm{Ks}$ agree well at low temperature, but deviate increasingly with increasing temperature until a difference of about $0.4 \log$ units exists at $250^{\circ} \mathrm{C}$, producing the observed differences in the affinity vs. temperature figures.

The $\log \mathrm{K}$ for reaction between $\mathrm{Al}^{3+}$ and $\mathrm{AlO}_{2}^{-}$from Bourcier and Knauss (1993) used in GEMBOCHS COM versions prior to R24 also reproduces observed mineralogy well. It would behoove future users of GEMBOCHS data bases to identify the $\mathrm{Al}(\mathrm{OH})_{4}{ }^{-} / \mathrm{Al}^{3+} \log \mathrm{K}$ specified in the data base they are using, and ascertain that it is appropriate for their needs. Of course, reactions which are written balanced on $\mathrm{Al}$, such as those incorporated in many activity diagrams (e.g Bowers and Burns, 1990; Chipera, Bish and Carlos, 1995), will not be affected.

\section{Thermodynamic data for wairakite}

Figures 3 through 8 illustrate that wairakite is predicted to be about 1 to $1.5 \mathrm{kcal} / \mathrm{mol}$ undersaturated in all wells at about $250^{\circ} \mathrm{C}$. In contrast, wairakite commonly occurs at Wairakei as a secondary phase at this temperature. Therefore, the calculations suggest that the free energy of formation from the elements of wairakite in SUPCRT92 (Helgeson et al., 1978) and in all current verions of GEMBOCHS should be decreased by approx. $1-1.5 \mathrm{kcal} / \mathrm{mol}$ at about $250^{\circ} \mathrm{C}$ to increase its stability.

2. Versions of SUPCRT have been published and distributed without data for $\mathrm{AlO}_{2}^{-}$, the most important $\mathrm{Al}$ aqueous species under most conditions. The calculations in this paper provided for this species. 
SUPCRT92 data base with Pokrovskii and Helgeson Al data

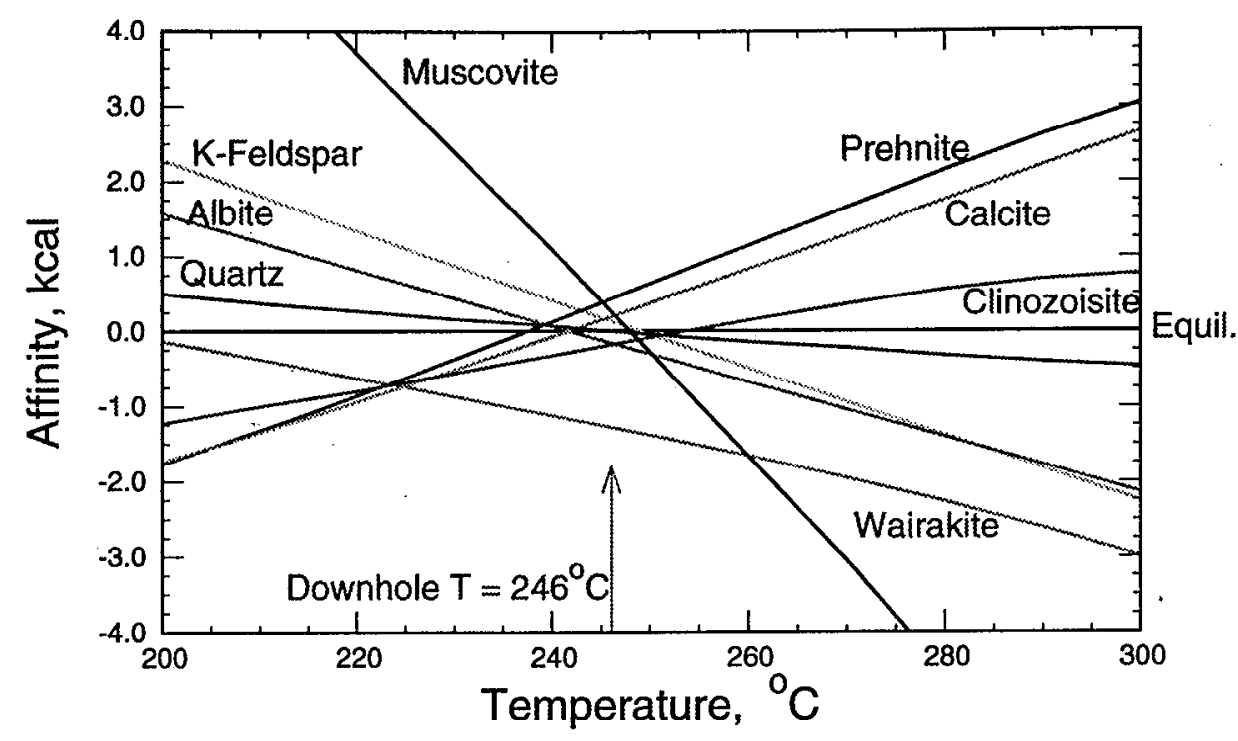

Figure 7. Affinity vs. temperature diagram for well WK-28 using thermodynamic data for $\mathrm{Al}$ aqueous species from Pokrovskii and Helgeson (in press). Quartz data from Fournier (1983).

\section{SUPCRT92 thermodynamic data}

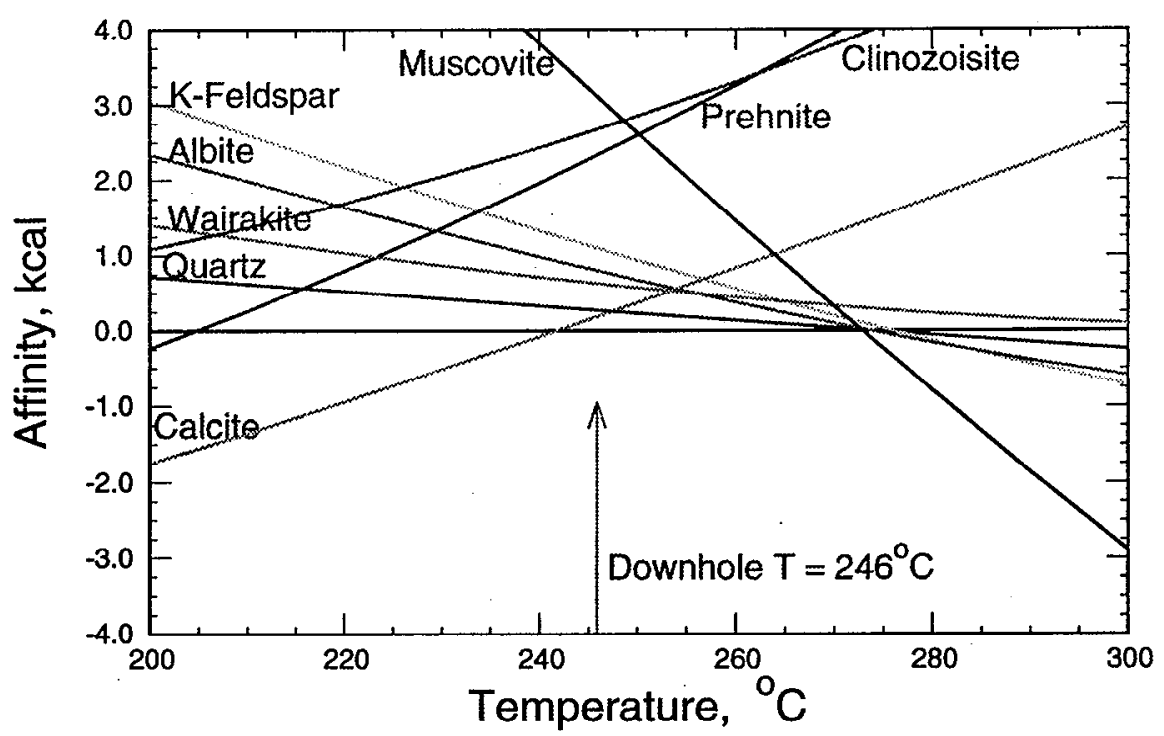

Figure 8. Affinity vs. temperature diagram for well WK-28 using thermodynamic data for Al aqueous species from the SUPCRT92 version of the GEMBOCHS data base. Quartz data from Walther and Helgeson (1977); contrast with Figure 7.

Thermodynamic data for wairakite may not seem to be relevant to the Yucca Mountain Project. However, if temperatures exceed $200^{\circ} \mathrm{C}$ with water present, wairakite would tend to be the stable zeolite relative to clinoptilolite, heulandite and mordenite. Given the uncertainty in thermodynamic data for lower temperature zeolites such as clinoptilolite, heulandite and morden- 
ite (discussed below), it is useful to have some measure of data reliability for at least one zeolite with which to reference the other zeolites.

\section{Thermodynamic data for zeolites}

The simulations represented in Figures 3 through 8 were run with the SUPCRT data base instead of the COM data file in part because the COM file contains thermodynamic data for zeolites such as analcime, clinoptilolite, mordenite, heulandite, stilbite, mesolite, scolecite and natrolite from Johnson and co-workers $(1982,1983,1985,1991,1992)$ and Howell et al. (1990). This data was obtained through careful calorimetric studies. When kinetic constraints are not considered and purely thermodynamic equilibrium calculations are made, one of the above zeolites is present in the computed equilibrium assemblage at temperatures as high as $250^{\circ} \mathrm{C}$, even though they are generally not expected to be stable at such high temperature in natural systems.

Figure 9 shows a calculation of zeolite stability in well WK-28 under conditions identical to

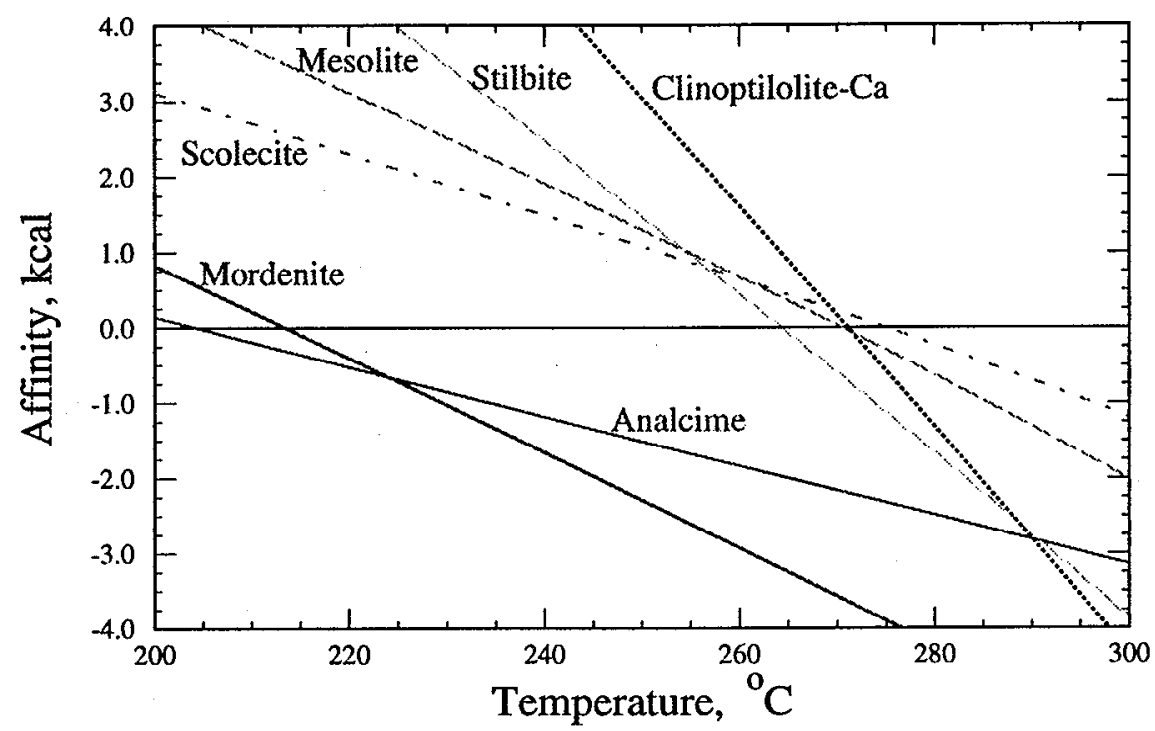

Figure 9. Zeolite affinities vs. temperature diagram for well WK28 using thermodynamic data for $\mathrm{Al}$ aqueous species from Pokrovskii and Helgeson (in press). See Figure 7 for stabilities of additional minerals. Clinoptilolite-Ca refers to the $\mathrm{Ca}$ end-member of a clinoptilolite solid solution.

that in Figure 7, but using GEMBOCHS version COM R24 which contains Johnson's calorimetric data for zeolites. Figure 7 can be combined with Figure 9 to show the affinities of zeolites relative to other minerals. Note the supersaturation with respect to scolecite, mesolite, stilbite and the $\mathrm{Ca}$ end-member of a clinoptilolite solid solution (discussed by Viani and Bruton, 1992) at the downhole temperature of $246^{\circ} \mathrm{C}$.

If EQ6 is asked to predict the stable mineral assemblage in equilibrium with this water, it first selects calcite, quartz and petalite $\left(\mathrm{LiAlSi}_{4} \mathrm{O}_{10}\right)$. Suppression of petalite yields an assemblage of calcite, quartz and mesolite. However, mesolite and the other supersaturated zeolites shown in 
Figure 9 are not found in the volcanic rocks at $250^{\circ} \mathrm{C}$. This suggests that there are problems with Johnson's data for zeolites, except for analcime ${ }^{3}$, in the GEMBOCHS COM data file.

Owing to this discovery, the first tests of the codes were made using data bases that do not contain Johnson's data for zeolites. At this time, simulations using the COM data base containing Johnson's zeolites must apparently be made by suppressing the zeolites to artificially reflect their disappearance from natural assemblages at temperatures greater than about $200^{\circ} \mathrm{C}$.

The thermodynamic data at elevated temperature for the above zeolites from Johnson and coworkers are uncertain for a number of reasons. First, the third law entropies for clinoptilolite, mordenite, stilbite, mesolite, scolecite and natrolite in the COM data file are actually values for $S^{\circ}(T)-S^{\circ}(0)$, because the configurational entropies at $0 \mathrm{~K}\left(S^{\circ}(0)\right)$ were not available. Johnson and co-workers attempted to estimate configurational entropies when possible, and warned that the configurational entropy must be taken into account when computing mineral equilibria. We have not devoted effort to estimating configurational entropies because their contribution would increase zeolite stability, whereas the problem is that they seem to be too stable already.

Secondly, it is possible that $\mathrm{H}_{2} \mathrm{O}$ vapor readsorption occurred during the cooling of Johnson's drop calorimetry experiments. The exothermic reaction would produce excess heat capacity at elevated temperature (see Carey, 1993 for full discussion). Carey (1993) suggested that the heat capacity of $\mathrm{H}_{2} \mathrm{O}$ in clinoptilolite is temperature-insensitive, rather than increasing monotonically with temperature, as shown by Johnson et al. (1991).

Thirdly, the hydration state of zeolites may decrease with increasing temperature, which would affect their stability. Water in zeolites is generally considered to have a lower free energy than bulk water, such that water desorption is endothermic. Johnson measured the thermodynamic properties of his zeolites at 50\% relative humidity in recognition of their potential for changing hydration state. This potential for changing hydration state is not currently provided for in the EQ3/6 codes and data bases, however.

If the configurational entropy were appropriately accounted for, and the heat capacities corrected for readsorption phenomena, the stability of zeolites would increase because their free energies of formation would be more negative. However, zeolite stability would have to decrease if errors in thermodynamic data were the cause for the predicted stability of zeolites at temperatures greater than about $200^{\circ} \mathrm{C}$.

Until a more satisfying approach is found, EQ3/6 calculations of fluid-mineral equilibria in the post-emplacement environment at temperatures greater than about $200^{\circ} \mathrm{C}$ will be carrried out by manually suppressing the precipitation of low temperature zeolites.

3. Analcime may be found at higher temperatures than clinoptilolite, mordenite, stilbite, scolecite, natrolite and mesolite. Johnson's data for analcime is actually preferable to that from Helgeson et al. (1978) because Johnson provided rigorously for the deviation of the composition of analcime from its idealized $\mathrm{NaAlSi}_{2} \mathrm{O}_{6}: \mathrm{H}_{2} \mathrm{O}$ formula in his investigation. 


\section{Ability to predict stable phase assemblages with $\mathrm{EO} 3 / 6$}

Affinity-temperature diagrams were used to illustrate that a number of minerals are close to equilibrium with downhole fluids at Wairakei (e.g. affinity close to 0 ). This might explain the wide variety of mineral assemblages observed at Wairakei. However, all assemblages are composed of different combinations of the same set of minerals. This common phenomenon is expressed by the metamorphic facies concept.

It is not feasible to use EQ6 to predict the exact assemblage of silicate minerals in equilibrium with a given fluid. ${ }^{4}$ The codes cannot be used to predict blindly the stable phase assemblage because the entire calculation is "led astray" if one mineral's thermodynamic data causes its stability to be overestimated, or if the code chooses a precipitate that is inappropriate because of kinetic constraints. For example, an example was mentioned previously in which EQ6 was used to predict the stable phase assemblage in equilibrium with the downhole fluid in WK-28. EQ6 predicted an assemblage of calcite, quartz and petalite (or mesolite) using the COM R24 data base. The same calculation made using the SUPCRT R24 data base yielded an assemblage of calcite, quartz, analcime and tremolite. Neither of these assemblages are representative of observed secondary (or primary) mineralogy.

In contrast, it is quite reasonable to use EQ3 and EQ6, when tempered with field and laboratory data and common sense, to establish facies of minerals that would be expected to precipitate under given conditions. Each facies would consist of classes of minerals that would possess similar characteristics, e.g. a class of silica-rich zeolites that contains clinoptilolite, mordenite and heulandite. This is eminently more reasonable than expecting to predict whether clinoptilolite, mordenite or heulandite will precipitate. We will not know in the near future the fluid composition nor the thermodyamic properties of minerals to the degree of accuracy required to do so.

Clearly, alternate approachs similar to that illustrated by the affinity-temperature diagrams should be adopted to determine the potential for mineral stability. The calculations described in Figures 3 through 8 suggest that fluid-mineral equilibria determined in this manner agree well with observed mineralogy.

\section{Vein/vug vs. matrix mineralogy and mineral assemblages}

Alteration mineralogy at Wairakei is controlled strongly by temperature in veins and vugs, and by both temperature and mineralogy in the matrix. ${ }^{5}$ Replacement minerals in the matrix are controlled in identity, morphology and location by the primary mineralogy. That is, replacement mineralogy is controlled by the dissolving phase; the components of the dissolving mineral tend to re-precipitate as secondary minerals next to the dissolving grain. This link is much weaker to non-existent in vein- and vug-fills.

\footnotetext{
4. This is a "single-point" calculation; that is, the fluid composition is specified, and EQ6 precipitates a series of minerals based on their normalized degree of supersaturation. The precipitation of each mineral changes the fluid composition, and so affects the degree of saturation of other minerals. This is in contrast to EQ6 calculations of mineral affinity with temperature, in which fluid composition (except $\mathrm{pH}$ and redox state) is held constant.

5. Primary mineralogy also seems to control features such as the Al:Si ratio of secondary minerals.
} 
The stabilities of fracture-, vein- and vug-filling minerals are controlled by solution composition and temperature with apparently limited control by the matrix. Alteration minerals in veins and vugs are the same as those found as replacement minerals in the matrix, but they occur in assemblages composed of fewer phases. It is striking that vein and vug fills, which obviously have precipitated from solution, are characterized by one to three secondary minerals, fewer than the number of different replacement minerals in the matrix as a whole. The above findings suggest that the fractures, veins and vugs represent fluid-dominated systems, whereas the matrix represents a rock-dominated system.

Petrographic observations suggest that the minerals replacing plagioclase in the matrix are those that commonly comprise fracture/vein/vug mineralogy; both seem to be Ca-dominated systems. At this time, our working hypothesis is that vein mineralogy is controlled mainly by fluid chemistry in the flowing system with negligible interaction with the host rock. The number of fracture-filling minerals may be controlled by the phase rule for mobile components. Investigations into the application of the phase rule to the number of minerals expected in a fracture-fill and the matrix are planned.

In the post-emplacement environment at Yucca Mountain, replacement mineralogy in the matrix would be expected to be controlled by temperature and primary mineralogy, provided sufficient water is present to effect such changes, whereas the stability of minerals along flow paths such as fractures would be controlled by the evolution of water composition as well as temperature. Factors that could impact water composition include boiling/condensation, interactions with cementitious and other manufactured materials including metal waste package components, and so on.

We are currently investigating the degree of mass transfer between matrix and fractures in the New Zealand systems. If there is little chemical exchange between the matrix and fractures, mineral dissolution/precipitation during fluid flow in coupled hydrogeochemical models can be simulated much more simply because diffusion to and from the matrix does not have to be considered. We are currently assessing field data to determine the extent to which the bulk rock, or matrix, changes composition during alteration.

\section{Conclusions}

Vein and matrix minerals are predicted to be in equilibrium with subsurface fluids at downhole temperatures greater than $240^{\circ} \mathrm{C}$. The proximity of a variety of minerals to equilibrium suggests that small differences in fluid chemistry, temperature or pressure can significantly impact mineral assemblages. This might account for the wide variety of mineral assemblages observed at Wairakei.

The SUPCRT92 data base combined with the data of Pokrovskii and Helgeson (in press) for aqueous $\mathrm{Al}$ species describes equilibrium relations between measured $\mathrm{Al}$ concentrations and observed mineral equilibria better than data in the current SUPCRT92 data base. Observed changes in the stability of calcite, prehnite and illite (muscovite) can be indicative of changes in the gas content of the downhole fluid. Feldspar stabilities are largely independent of $\mathrm{pH}$.

Quartz solubility data from Fournier (1983) describe observed mineral assemblages better than data from Walther and Helgeson (1977). The free energy of wairakite from Helgeson et al. 
(1978) should be decreased by approximately $1-1.5 \mathrm{kcal} / \mathrm{mole}$ at about $250^{\circ} \mathrm{C}$. Additional work is required to determine why calorimetric data for clinoptilolite, stilbite and other zeolites from Johnson and co-workers appear to over-estimate the stability of these minerals at elevated temperature.

Fluid-mineral interactions at temperatures $>200^{\circ} \mathrm{C}$ are generally believed to be controlled by equilibrium, and so were chosen as the starting point for the EQ3/6 code and data base tests. Additional studies will now focus on fluid-mineral reactions in the temperature range of about $100-200^{\circ} \mathrm{C}$ at the Wairakei and Kawerau geothermal fields. Zeolites such as mordenite, dachiardite and clinoptilolite have been identified in this temperature interval. Extension of the tests to lower temperature allows us to address the controls of kinetics vs. equilibrium on mineral stability, and to determine the stability of zeolites similar to those found at Yucca Mountain. 


\section{References}

Arthur, R.C. and Murphy, W.M., 1989, An analysis of gas-water-rock interactions during boiling in partially saturated tuff: Soc. Geol., Bull., v. 42, p. 313-327.

Bird, D.K. and Helgeson, H.C., 1980, Chemical interaction of aqueous solutions with epidotefeldspar mineral assemblages in geologic systems. 1. Thermodynamic analysis of phase relations in the system $\mathrm{CaO}-\mathrm{FeO}-\mathrm{Fe}_{2} \mathrm{O}_{3}-\mathrm{Al}_{2} \mathrm{O}_{3}-\mathrm{SiO}_{2}-\mathrm{H}_{2} \mathrm{O}-\mathrm{CO}_{2}$ : Am. Jour. Sci., v. 280, p. 907-941.

Bourcier, W.L. and Knauss, K.G., 1993, Aluminum hydrolysis constants to $250^{\circ} \mathrm{C}$ from boehmite solubility measurements: Geochim. et Cosmochim. Acta, v. 57, p. 747-762.

Bowers, T.S. and Burns, R.G., 1990, Activity diagrams for clinoptilolite: Susceptibility of this zeolite to further diagenetic reactions: Am. Min., v. 75, p. 601-619.

Bruton, C.J., Glassley, W.E. and Bourcier, W.L., 1994, Field-based tests of geochemical modeling codes using New Zealand hydrothermal systems: Lawrence Livermore National Laboratory UCRL-ID-118009.

Bruton, C.J., Glassley, W.E. and Meike, A., 1995, Geothermal areas as analogues to chemical processes in the near-field and altered zone of the potential Yucca Mountain, Nevada repository: Lawrence Livermore National Laboratory UCRL-ID-119842 (currently under Yucca Mountain review).

Bruton, C.J. and Viani, B.E., 1992, Geochemical modeling of water-rock interactions in the unsaturated zone: In Water-Rock Interaction 7, Y.K. Kharaka and A.S. Maest, eds., A.A. Balkema, Netherlands, p. 705-708.

Buscheck, T.A. and Nitao, J.J., 1993, Repository-heat-driven hydrothermal flow at Yucca Mountain, Part 1: Modeling and analysis: Nuclear Tech., v. 104, p. 418-448.

Carey, J.W., 1993, The heat capacity of hydrous cordierite above 295 K: Phys. Chem. Min., v. 19, p. $578-583$.

Chipera, S.J., Bish, D.L. and Carlos, B.A., 1995, Equilibrium modeling of the formation of zeolites in fractures at Yucca Mountain, Nevada: In D.W. Ming and F.A. Mumpton, eds., Natural Zeolites '93: Occurrence, Properties, Use: Intl. Comm. on Natl. Zeolites, Brockport, N.Y., p. 565577.

Christenson, B.W., 1987, Fluid-mineral equilibria in the Kawerau hydrothermal system, Taupo Volcanic Zone, New Zealand: Ph.D. thesis, Univ. of Auckland, New Zealand.

Criscenti, L.J. and Arthur, R.C., 1991, The calculated effects of isothermal boiling on tuff-water interactions: Radiochim. Acta, v. 52/53, p. 513-517.

Fournier, R.O., 1983, A method of calculating quartz solubilities in aqueous sodium chloride solutions: Geochim. et Cosmochim. Acta, v. 47, p. 579-586.

Helgeson, H.C., Delany, J.M., Nesbitt, H.W. and D.K. Bird, 1978, Summary and critique of the thermodynamic properties of rock-forming minerals: Am. Jour. Sci., v. 278-A, p. 1-228.

Henley, R.W., Truesdell, A.H. and Barton, Jr., P.B., 1984, Fluid-mineral equilibria in hydrothermal systems, Rev. in Econ. Geol. Vol. 1: Soc. of Econ. Geol., Univ. of Texas, El Paso, Texas.

Howell, D.A., Johnson, G.K., Tasker, I.R. and O'Hare, P.A.G., 1990, Thermodynamic studies of the zeolite stilbite: Zeolites, v. 10, July/August, p. 525-531.

Johnson, G.K., Flotow, H.E. and O'Hare, P.A.G., 1982, Thermodynamic studies of zeolites: analcime and dehydrated analcime: Am. Min., v. 67, p. 736-748. 
Johnson, G.K., Flotow, H.E. and O'Hare, P.A.G., 1983, Thermodynamic studies of zeolites: natrolite, mesolite and scolecite: Am. Min., v. 87, p. 1134-1145.

Johnson, G.K., Flotow, H.E. and O'Hare, P.A.G., 1985, Thermodynamic studies of zeolites: heulandite: Am. Min., v. 70, p. 1065-1071.

Johnson, G.K., Tasker, I.R., Flotow, H.E., O'Hare, P.A.G. and Wise, W.S., 1992, Thermodynamic studies of mordenite, dehydrated mordenite, and gibbsite: Am. Min., v. 77, p. 85-93.

Johnson, G.K., Tasker, I.R., Jurgens, R. and O'Hare, P.A.G., 1991, Thermodynamic studies of zeolites: clinoptilolite: J. Chem. Thermo., v. 23, p. 475-484.

Pokrovskii, V.A. and Helgeson, H.C., 1995, Thermodynamic properties of aqueous species and the solubilities of minerals at high pressures and temperatures: The system $\mathrm{Al}_{2} \mathrm{O}_{3}-\mathrm{H}_{2} \mathrm{O}-\mathrm{NaCl}$ : Am. Jour. Sci., v. 295, in press.

Ragnarsdottir, K.V. and Walther, J.V., 1983, Pressure sensitive "silica geothermometer" determined from quartz solubility experiments at $250^{\circ} \mathrm{C}$ : Geochim. et Cosmochim. Acta, v. 47, p. 941946.

Reyes, A.G., Giggenbach, W.F. and Christenson, B.W., 1993, First Report for the LLNL-Inst. Geol. Nuclear Sciences EQ3-EQ6 Code Validation Contract: Inst. Geol. Nuclear Sciences Client Report 722305.15A.

Reyes, A.G., Giggenbach, W.F. and Christenson, B.W., 1994, Third Report for the LLNL-Inst. Geol. Nuclear Sciences EQ3-EQ6 Code Validation Contract: Inst. Geol. Nuclear Sciences Client Report 724305.15C.

Steiner, A., 1977, The Wairakei geothermal area, North Island, New Zealand: New Zealand Geological Survey Bull. 90.

Viani, B.E. and Bruton, C.J., 1992, Modeling fluid-rock interaction at Yucca Mountain, Nevada: A progress report: Lawrence Livermore National Laboratory UCRL-ID-109921.

Walther, J.V. and Helgeson, H.C., 1977, Calculation of the thermodynamic properties of aqueous silica and the solubility of quartz and its polymorphs at high pressures and temperatures: Am. Jour. Sci., v. 277, p. 1315-1351.

Wolery, T.J., 1992, EQ3NR, A computer program for geochemical aqueous speciation-solubility calculations: Theoretical manual, user's guide, and related documentation (Version 7.0): Lawrence Livermore National Laboratory Report UCRL-MA-110662 PT III.

Wolery, T.J. and Daveler, S.A., 1992, EQ6, A computer program for reaction path modeling of aqueous geochemical systems: Theoretical manual, user's guide, and related documentation (Version 7.0): Lawrence Livermore National Laboratory Report UCRL-MA-110662 PT IV.

Note: New Zealand Institute of Geological and Nuclear Sciences Client Report 724305.15C by Reyes, Giggenbach and Christenson (1994) prepared for LLNL under Subcontract B298283 is included as part of this letter report. Client Report 722305.15A by Reyes, Giggenbach and Christenson (1993) was submitted as part of a letter report submitted for milestone MOL24 on July 27 , 1994. 


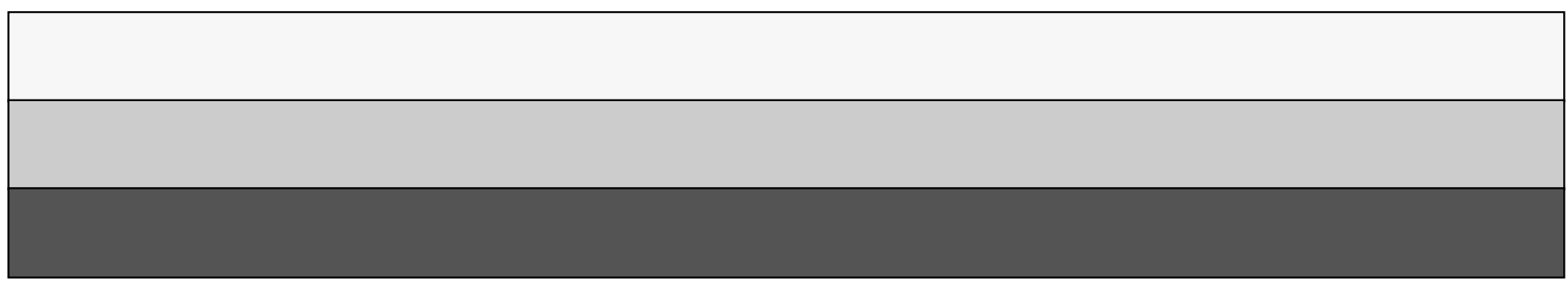

